\title{
Pengaruh Model Pembelajaran Numbered Head Together (NHT) terhadap Hasil Belajar Fisika Siswa Kelas VIII SMP Negeri 19 Palu
}

\author{
Hikmah Basonggo, Darsikin, dan Marungkil Pasaribu \\ hikmahby94@gmail.com \\ Program Studi Pendidikan Fisika FKIP Universitas Tadulako \\ Jl. Soekarno Hatta Km. 9 Kampus Bumi Tadulako Tondo Palu - Sulawesi Tengah
}

\begin{abstract}
Abstrak - Penelitian ini bertujuan untuk mengetahui ada tidaknya pengaruh model pembelajaran Numbered Head Together (NHT) terhadap hasil belajar fisika siswa kelas VIII SMP Negeri 19 Palu. Jenis penelitian ini adalah eksperimen kuasi dengan desain penelitian equivalent pretest-posttest.Populasi dalam penelitian ini adalah seluruh siswa kelas VIII SMP Negeri 19 Palu, dengan sampel penelitian yaitu kelas VIII A sebagai kelas eksperimen dan kelas VIII B sebagai kelas kontrol, yang dipilih dengan menggunakan teknik purposive sampling.Instrumen penelitian yang digunakan adalah tes esai sebanyak 10 nomor dan perangkat pembelajaran yang telah divalidasi oleh validator ahli. Hasil analisa data diperoleh rerata skor pretest untuk kelas eksperimen yaitu 13,77 dan untuk kelas kontrol yaitu 13,41. Sedangkan rerata skor posttest untuk kelas eksperimen diperoleh 30,18 dan kelas kontrol diperoleh 25,18. Hasil penelitian ini diuji dengan menggunakan uji-t dua pihak. Berdasarkan hasil akhir perhitungan diperoleh $t_{\text {hitung }}=3,39$ dan $t_{\text {tabel }}=1,68$ atau nilait $t_{\text {hitung }}>$

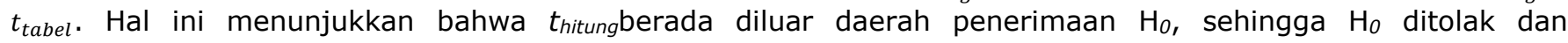
$\mathrm{H}_{1}$ diterima.Dengan demikian, dapat disimpulkan bahwa terdapat pengaruh model pembelajaran Numbered Head Together (NHT) terhadap hasil belajar fisika siswa kelas VIII SMP Negeri 19 Palu.
\end{abstract}

Kata Kunci: model pembelajaran numbered head together (NHT), hasil belajar fisika

\section{PENDAHULUAN}

Dalam pembelajaran sains, terutama pembelajaran fisika, proses membangun pengetahuan sendiri bagi peserta didik sangatlah penting. Peserta didik hanya akan mengerti dengan sungguh-sungguh dan mempunyai kompetisi dalam bidang fisika yang digeluti bila peserta didik sendiri aktif belajar, mengelolah, mencerna dan merumuskannya dipikirannya sendiri [1]. Tujuan pembelajaran fisika adalah untuk mengantarkan siswa menguasai konsep fisika dan keterkaitannya untuk memecahkan masalah yang berhubungan dengan kehidupan sehari-hari. Artinya pembelajaran fisika harus menjadikan siswa tidak sekedar tahu dan hafal tentang konsep fisika melainkan harus menjadikan siswa untuk mengerti dan memahami konsep tersebut dan menghubungkan keterkaitan suatu konsep dengan konsep lain [2].

Tercapainya tujuan pembelajaran fisika tersebut salah satunya dapat dilihat dari pencapaian hasil belajar siswa yang sesuai dengan tujuan pembelajaran yang telah ditetapkan. Hasil belajar merupakan pencapaian yang diperoleh siswa setelah mempelajari suatu materi pembelajaran, yang dinyatakan dalam bentuk skor yang diperoleh dari evaluasi pembelajaran berupa tes. Terwujudnya hasil belajar yang maksimal dipengaruhi oleh beberapa faktor diantaranya kesiapan belajar siswa, guru dan lingkungan belajar. Guru sebagai pelaku utama dalam penerapan program pendidikan di sekolah memiliki peran yang sangat penting dalam pencapaian tujuan pendidikan yang diharapakan [3].

Berdasarkan hasil observasi, diperoleh informasi bahwa kegiatan pembelajaran di SMP Negeri 19 Palu kebanyakan masih menggunakan metode ceramah dalam penyampaian materi di dalam kelas. Sehingga siswa lebih cenderung hanya mendengarkan dan mencatat apa yang dijelaskan oleh guru. Hal tersebut mengakibatkan siswa menjadi pasif, dimana siswa terkesan berada pada proses pembelajaran yang dikenal dengan duduk, diam, dengar, hafal dan catat.

Sehubungan dengan masalah tersebut, maka guru harus kreatifitas dalam memilih suatu model pembelajaran yang tepat, khususnya pada pelajaran fisika. Karena dalam Pembelajaran fisika tidak hanya sekedar menghafal dan mengingat materi yang disajikan, melainkan siswa harus mampu mengkaji, memahami serta memecahkan berbagai masalah yang berkaitan dengan persamaan dan hukum yang berkaitan dengan fisika. Salah satu alternatif model pembelajaran yang dapat meningkatkan hasil belajar siswa yaitu model pembelajaran Numbered Head Together (NHT). 
Model NHT dapat meningkatkan hasil pembelajaran siswa. Model NHT dirancang untuk melibatkan lebih banyak siswa dalam menelaah materi yang tercakup dalam suatu pelajaran dan mengecek pemahaman mereka terhadap isi pelajaran tersebut. Ciri khasnya adalah guru menunjuk salah satu nomor (siswa) secara acak untuk mempresentasikan hasil kegiatan berpikir besama kelompoknya. Pemanggilan siswa secara acak akan menjamin keterlibatan total semua siswa, karena dengan pemanggilan secara acak siswa menjadi siap semua. Model pembelajaran NHT juga dapat mendorong siswa untuk meningkatkan kerja sama mereka. Setiap siswa mendapat kesempatan sama untuk mengoptimalkan kerja kelompoknya dalam mendapatkan nilai yang maksimum [4].

Keefektifan model pembelajaran NHT sebelumnya telah dibuktikan pada penelitian terdahulu [5]. Model kooperatif tipe NHT dapat berpengaruh terhadap hasil belajar siswa pada materi kimia koloid. Dimana pembelajaran dengan menggunakan model NHT memberikan hasil belajar yang lebih tinggi dibandingkan dengan menggunakan model pembelajaran konvensional. Selain itu, siswa dalam model pembelajaran NHT menjadi lebih bisa mengaktifkan diri pada saat proses pembelajaran serta mampu bekerjasama dalam menyelesaikan permasalahan dalam belajar. Penelitian lainnya [6] menyimpulkan bahwa model pembelajaran NHT dapat meningkatkan prestasi belajar IPA siswa. Hal tersebut ditunjukkan dengan melihat perolehan nilai ketuntasan klasikal sebelum adanya perlakuan yaitu sebesar $46 \%$ dan meningkat menjadi $85 \%$ dengan kualifikasi sangat baik.

Model NHT yang dimaksud dalam penelitian ini adalah model pembelajaran kooperatif yang dapat meningkatkan penguasaan akademik, mengaktifkan siswa dalam proses belajar mengajar, serta dapat mempengaruhi pola interaksi siswa. Sedangkan hasil belajar yang dimaksudkan pada penelitian ini adalah pencapaian yang diperoleh siswa setelah mempelajari suatu materi pemebelajaran, yang ditandai dengan adanya perubahan pada diri siswa tersebut. Dengan kata lain hasil belajar merupakan tolok ukur tentang berhasil tidaknya menempuh pembelajaran di sekolah, dimana untuk mengetahui tingkat keberhasilannya maka akan dilakukan evaluasi berupa tes.

Rumusan masalah pada penelitian adalah apakah terdapat pengaruh model pembelajaran Numbered Head Together (NHT) terhadap hasil belajar fisika siswa Kelas VIII SMP Negeri 19 Palu. Dengan hipotesis :
$\mathrm{H}_{0}$ : tidak terdapat pengaruh model pembelajaran Numbered Head Together (NHT) terhadap hasil belajar fisika siswa antara kelas eksperimen dengan kelas kontrol.

$\mathrm{H}_{1}$ : terdapat pengaruh model pembelajaran Numbered Head Together (NHT) terhadap hasil belajar fisika siswa antara kelas eksperimen dengan kelas kontrol.

Tujuan penelitian ini yaitu untuk mengetahui ada tidaknya pengaruh model pembelajaran Numbered Head Together (NHT) terhadap hasil belajar fisika siswa kelas VIII SMP Negaeri 19 Palu.

Perbedaan penelitian ini dengan penelitian sebelumnya yaitu pada penelitian sebelumnya fokus pada hasil belajar kimia koloid dan prestasi belajar siswa. Sedangkan penelitian ini lebih memfokuskan pada hasil belajar fisika siswa dengan melihat pencapaian yang diperoleh siswa setelah mempelajari suatu materi pembelajaran.

\section{METODE PENELITIAN}

Penelitian yang digunakan adalah jenis jenis penelitian kuantitatif yang bersifat eksperimen quasi, dengan desain penelitian yang digunakan adalah "Equivalen Prettest-Posttest Design" atau (Rancangan Prates-Pascates yang Ekuivalen). Bentuk desain penelitian ini dapat dilihat pada Tabel 1.

\begin{tabular}{cccc} 
TABEL 1 DESAIN PENELITIAN & & \\
\hline Kelompok & Prates & Perlakuan & Pascates \\
\hline Eksperimen & $\mathrm{O}$ & $\mathrm{X}$ & $\mathrm{O}$ \\
Kontrol & $\mathrm{O}$ & - & $\mathrm{O}$ \\
\hline
\end{tabular}

Keterangan:

$X$ :Perlakuan dengan model pembelajaran NHT

$\mathrm{O}$ :Tes awal dan tes akhir (pretest dan posttest)

Penelitian ini dilakukan di SMP Negeri 19 Palu. Jalan Untad 1, Bumi Roviga Tondo. Waktu pelaksanaa penelitian ini dilaksanakan pada semester genap, tahun ajaran 2016/2017. Populasi dalam penelitian ini yaitu seluruh siswa kelas VIII SMP Negeri 19 Palu dengan sampel penelitian adalah kelas VIII A sebagai kelas eksperimen dan kelas VIII B sebagai kelas kontrol, yang dipilih dari keseluruhan populasi dengan menggunakan teknik purposive sampling yaitu penentuan sampel dengan pertimbangan tertentu.

Instrumen yang digunakan dalam penelitian ini adalah esai tes untuk mengetahui hasil belajar siswa pada mata pelajaran fisika yang telah divalidasi oleh validator ahli. Analisis data dilakukan dengan menganalisis data hasil 
penelitian menggunakan uji normalitas, uji homogenitas dan uji hipotesis. Instrumen pada penelitian ini dilakukan validasi langsung oleh validator ahli yang berkompeten mengenai tes hasil belajar fisika. Dalam hal ini tes dibuat dalam bentuk esai sebanyak 10 nomor, dengan ke 10 nomor soal tersebut dinyatakan valid. Adapun untuk perangkat pembelajaran terdiri dari Rencana Pelaksanaan Pembelajaran (RPP) dan Lembar Kerja Siswa (LKK) yang masingmasingnya dibuat sebanyak 5 kali pertemuan yang telah dilakukan validitas isi perangkat pembelajaran oleh validator ahli dan dinyatakan valid serta dapat digunakan sebagai perangkat pembelajaran di dalam kelas.

\section{HASIL DAN PEMBAHASAN}

\section{A. Hasil Penelitian}

1. Uji Normalitas

Data yang diperoleh dari hasil penelitian ini dilakukan pengujian normalitas dengan menggunakan uji Chi-kuadrat dengan kriteria penerimaan $X^{2}$ Hitung $<X^{2}$ tabel, taraf signifikansi $a=$ 0,05 dan derajat kebebasan $\mathrm{dk}=\mathrm{k}-3$. Berdasarkan hasil perhitungan pretest, diperoleh nilai $X^{2}$ Hitung kelas eksperiman sebesar 2,47 dan untuk kelas kelas kontrol diperoleh 3,13 . Sedangkan untuk hasil perhitungan posttest, nilai $X^{2}$ Hitung yang diperoleh kelas eksperimen sebesar 4,76 dan untuk kelas kontrol diperoleh 6,58. Hasil data tersebut dapat dilihat pada Tabel 2berikut :

TABEL 2 HASIL UJI NORMALITAS PRETES-POSSTESTKELAS EKSPERIMEN

\begin{tabular}{lcccc}
\multicolumn{4}{c}{ DAN KELAS KONTROL } \\
\hline Uraian & \multicolumn{2}{c}{ Pretest } & \multicolumn{2}{c}{ Posttest } \\
\hline & Eksperimen & Kontrol & Eksperimen & Kontrol \\
Sampel & 22 & 22 & 22 & 22 \\
\hline$\chi^{2}$ hitung & 2,47 & 3,13 & 4,76 & 6,58 \\
\hline$\chi^{2}$ tabel & \multicolumn{2}{c}{7,81} & \multicolumn{2}{c}{7,81} \\
$(\mathrm{a}=0,05)$ & Berdistribusi & Berdistribusi \\
& Normal & Normal \\
\hline
\end{tabular}

Berdasarkan hasil uji normalitas pada Tabel 2 menggunakan Chi-kuadrat dengan kriteria penerimaan $\chi^{2}$ hitung $<\chi^{2}$ tabel, baik itu data pretest maupun data posttest, diperoleh nilai $\chi^{2}$ hitung lebih kecil daripada nilai $\chi^{2}$ tabel. Sehingga dapat disimpulkan bahwa kedua data tersebut berdistribusi normal.

\section{Uji Homogenitas}

Uji homogenitas pada penelitian ini menggunakan uji statistik Fisher (Uji F) dengan kriteria Fhitung $<$ Ftabel pada taraf signifikan $a=$ 0,05 . Uji homogenitas dilakukan untuk melihat apakah data berasal dari varians yang sama atau tidak. Hasil yang diperoleh untuk pretest nilai varians pada kelas eksperimen yaitu 10,39 dan untuk kelas kontrol diperoleh 9,71. Berdasarkan hasil perhitungan, diperoleh nilai Fhitung sebesar 1,07 dengan nilai $F_{\text {tabel }}$ 2,07. Sedangkan untuk hasil posttest, diperolehnilai varians kelas eksperimen yaitu 20,51 dan untuk kelas kontrol diperoleh 29,08. Beradasarkan hasil perhitungan, diperoleh nilai Fhitung 1,42 dengan nilai $F_{\text {tabel }} 2,07$. Hasil data tersebut dapat dilihat pada Tabel 3 berikut :

TABEL 3 UJI HOMOGENITAS PRETES-POSSTESTKELAS EKSPERIMEN DAN

\begin{tabular}{|c|c|c|c|c|}
\hline \multirow{2}{*}{$\begin{array}{l}\text { Uraian } \\
\text { Nilai } \\
\text { Varians }\end{array}$} & \multicolumn{2}{|c|}{ Pretest } & \multicolumn{2}{|c|}{ Posttest } \\
\hline & $\begin{array}{c}\text { Eksperimen } \\
10,39\end{array}$ & $\begin{array}{c}\text { Kontrol } \\
9,71\end{array}$ & $\begin{array}{l}\text { Eksperimen } \\
20,52\end{array}$ & $\begin{array}{c}\text { Kontrol } \\
29,08\end{array}$ \\
\hline Nilai $F_{\text {hitung }}$ & \multicolumn{2}{|c|}{1,07} & \multicolumn{2}{|c|}{1,42} \\
\hline $\begin{array}{l}F_{\text {tabel }} \\
(a=0,0)\end{array}$ & \multicolumn{2}{|c|}{2,07} & \multicolumn{2}{|c|}{2,07} \\
\hline Keputusan & \multicolumn{2}{|c|}{ Homogen } & \multicolumn{2}{|c|}{ Homogen } \\
\hline
\end{tabular}

Berdasarkan hasil uji homogenitas pada Tabel 3 dengan taraf signifikansi $(a=0,05)$, dari data tersebut terlihat bahwa Fhitung lebih kecil dari Ftabel atau Fhitung $<F_{\text {tabel, Maka }}$ berdasarkan kriteria pengambilan keputusan dapat disimpulkan bahwa varians antara kelas eksperimen dan kelas kontrol adalah sama atau homogen.

\section{Uji Hipotesis}

Uji hipotesis pada penelitian ini menggunakan uji statistika parametrik uji-t, dengan kriteria pengujinya adalah $\mathrm{H}_{0}$ diterima jika $-t_{\left(1-\frac{1}{2} \alpha\right)}<t<t_{\left(1-\frac{1}{2} \alpha\right)}$ dan dalam hal lain $\mathrm{H}_{0}$ ditolak. Hasil uji hipotesis pretes-posstest kelas eksperimen dan kelas kontrol dapat dilihat pada Tabel 4 berikut :

TABEL 4 UJI HIPOTESIS PRETES-POSSTEST KELAS EKSPERIMEN DAN

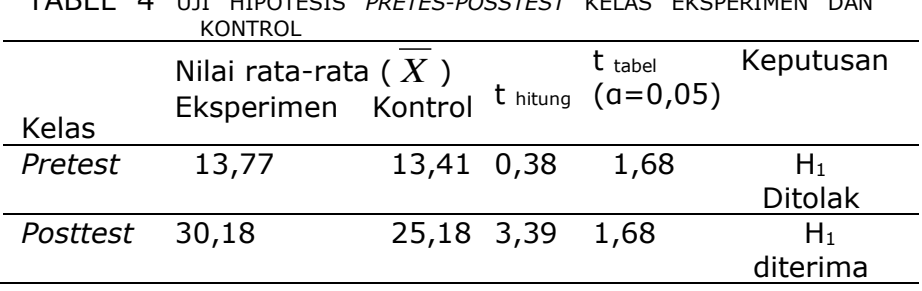

Berdasarkan hasil uji hipotesis pada Tabel 4, terlihat untuk pretest thitung adalah 0,38 dan $t_{\text {tabel }}$ adalah 1,68 . Hal ini menunjukkan bahwa thitung berada diantara $-1,68$ dan 1,68 , dengan demikian maka thitung berada didalam daerah penerimaan $\mathrm{H}_{0}$, sehingga $\mathrm{H}_{0}$ diterima dan $\mathrm{H}_{1}$ ditolak. Hal tersebut menunjukkan bahwa tidak terjadi perbedaan yang signifikan terhadap hasil belajar fisika antara kelas yang mengikuti 
model pembelajaran NHT dengan model pembelajaran konvensional. Sedangkan untuk posstest diperoleh hasil thitung adalah 3,39 dan $t_{\text {tabel }}$ adalah 1,68 . Hal ini menunjukkan bahwa

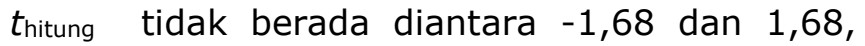
dengan demikian maka thitung berada diluar daerah penerimaan $\mathrm{H}_{0}$, sehingga $\mathrm{H}_{0}$ ditolak dan $\mathrm{H}_{1}$ diterima. Hal tersebut menunjukkan bahwa terdapat perbedaan rata-rata hasil belajar fisika antara kelas eksperimen dan kelas kontrol. Hasil ini menunjukkan bahwa terdapat pengaruh model pembelajaran NHT terhadaphasil belajar fisika siswa kelas VIII SMP Negeri 19 Palu.

\section{B. Pembahasan}

Berdasarkan analisis kuantitatif pada data posstest, diketahui bahwa nilai rata-rata kelas eksperimen lebih besar dibandingkan dengan nilai rata-rata pada kelas kontrol, dimana pada kelas eksperimen menggunakan model pembelajaran NHT sedangkan pada kelas kontrol menggunakan model konvesional. Perbedaan rerata skor pada kedua kelas tersebut menunjukkan adanya pengaruh signifikan dari model pembelajaran NHT. Hasil tersebut didukung dengan adanya uji hipotesis yaitu uji-t dengan hasil akhir perolehan nilai $t_{\text {hitung }}=3,39$ dan $t_{\text {tabel }}=1,68$ atau nilai $t_{\text {hitung }}>$ tabel, diketahui bahwa $\mathrm{H}_{0}$ ditolak atau $\mathrm{H}_{1}$ diterima. Artinya terdapat pengaruh hasil belajar fisika siswa antara kelas yang diberikan pembelajaran model $N H T$ dengan kelas yang menggunakan pembelajaran model konvensional.

Terdapatnya pengaruh model NHT terhadap hasil belajar, karena pada pembelajaran model NHT siswa diarahkan untuk memaparkan hasil jawaban kelompoknya. Dalam hal ini peneliti menyebutkan salah satu nomor dari masingmasing kelompok untuk memaparkan hasilnya, tanpa memberi tahu terlebih dahulu siapa yang akan mewakili kelompoknya. Hal tersebut bertujuan agar siswa tidak sekedar berpangku tangan saja melainkan mempersiapkan dirinya masing-masing untuk bertanggung jawab atas kelompoknya. Siswa yang disebutkan nomornya kemudian berdiri untuk memaparkan hasil kelompoknya dan kelompok lain menanggapinya. Dalam hal ini siswa dan peneliti sama-sama melihat kesamaan dan perbedaan yang terdapat dari hasil pekerjaan yang ada. Peran peneliti sangatlah penting sebagai fasilitator untuk merampungkan jawaban yang disepakati bersama.

Berdasarkan pengamatan yang peneliti lakukan, siswa pada kelas eksperimen sangatlah berantusias dan aktif selama proses untuk belajar. Siswa pada kelas eksperimen jauh memiliki kesiapan untuk menjawab maupun menyelesaikan permasalahan yang dihadapi dalam kelompoknya. Siswa yang awalnya pemalu menjadi berani dan percaya diri untuk mengutarakan pendapatnya serta bertanya pada teman kelompoknya dan peneliti, sedangkan siswa yang mempunyai pengetahuan lebih dapat mengajari siswa lainnya yang kurang pandai. Selain itu, siswa pada kelas eksperimen mudah dikondisikan dan memiliki rasa keingintahuan yang tinggi dengan banyak bertanya ketika ada penjelasan peneliti yang dianggap kurang jelas. Bahkan ketika ada siswa lain bertanya perihal yang belum dipahaminya, siswa yang merasa mengetahui jawaban dari pertanyaan temannya tersebut langsung mengancungkan tangan guna meminta izin pada peneliti untuk menjawab pertanyaan tersebut. Hal tersebut menunjukkan bahwa siswa pada kelas eksperimen secara optimal terlibat aktif dalam proses pembelajaran, sehingga diperoleh hasil pembelajaran yang lebih tinggi.

Berbeda dengan kelas kontrol yang menggunakan model konvensional sebagai pembanding dari kelas ekpserimen yang menggunakan model pembelajaran NHT. Pada pembelajaran konvensional, peneliti menggunakan metode ceramah dan tanya jawab dalam proses penyampaian materi dan meminta siswa untuk menuliskan atau menggaris bawahi bagian yang dianggap penting. Selanjutnya peneliti mengecek pemahaman siswa dengan memberikan soal latihan kepada siswa untuk dikerjakan. Peneliti kemudian memperhatikan jawaban siswa serta mengoreksinya untuk kemudian membetulkannya jika terdapat kesalahan. Dalam pembelajaran ini, kebanyakan siswa hanya mengharapkan informasi dari peneliti tanpa mau mencari solusi sendiri ketika diperhadapkan dengan permasalahan. Banyak siswa yang terlihat sibuk sendiri bahkan mengantuk. Ketika peneliti mengajukan pertanyaan untuk mengecek daya serap mereka terhadap materi pembelajaran, sebagaian siswa terlihat bingung dan bersikap acuh tak acuh. Mereka dominan mengharapkan siswa lain yang dianggapnya memiliki pengetahuan lebih untuk menjawab pertanyaan tersebut. Siswa dalam pembelajaran ini terilihat bersikap pasif selama proses pembelajaran berlangsung. Hal inilah yang membuat pencapaian hasil belajar pada kelas kontrol yang menjadi rendah.

Hasil penelitian ini didukung dengan penelitian sebelumnya. Penelitian sebelumnya [7] menyimpulkan bahwa penggunaan model 
pembelajaran kooperatif tipe $N H T$ hasilnya lebih baik dari pada model pembelajaran konvensional. Hal tersebut terlihat dari rerata hasil belajar siswa yang diajar dengan menggunakan model pembelajaran kooperatif tipe $N H T$ lebih tinggi dari rerata hasil belajar siswa yang diajar dengan model pembelajaran konvensional. Pembelajaran dengan menggunakan model NHT memiliki pengaruh positif terhadap hasil belajar juga lebih efektif untuk digunakan karena siswa dituntut terlibat langsung dalam kegiatan belajar-mengajar di kelas [8].

Adapun kelebihan dari model pembelajaran NHT dibandingkan dengan model pembelajaran konvesional yaitu model ini mampu mengoptimalkan siswa secara keseluruhan untuk terlibat aktif dalam proses pembelajaran, bekerjasama dan berani untuk mengutarakan pendapat, serta mampu menumbuhkan rasa tanggung jawab terhadap pribadi siswa.

\section{KESIMPULAN DAN SARAN}

\section{A. Kesimpulan}

Dari hasil penelitian dapat disimpulkan bahwa :

1. Terdapat pengaruh model pembelajaran Numbered Head Together (NHT) terhadap hasl belajar fisika siswa kelas VIII SMP Negeri 19 Palu.

2. Terjadi peningkatan yang signifikan pada hasil belajar fisika siswa kelas VIII SMP Negeri 19 Palu setelah mengikuti proses pembelajaran dengan menggunkan model pembelajaran Numbered Head Together (NHT).

\section{B. Saran}

Berdasarkan penelitian yang telah dilakukan, peneliti mengajukan beberapa saran sebagai berikut:

1. Guru diharapkan dapat menggunakan model pembelajaran NHT sebagai salah satu alternatif untuk memperoleh hasil belajar yang lebih tinggi dan lebih baik.

2. Dalam penelitian ini dengan menggunakan model pembelajaran $N H T$, peneliti hanya melihat pengaruhnya terhadap hasil belajar fisika siswa. Untuk pengembangan dari penelitian ini, alangkah baiknya jika ada penelitian lanjut yang menggunakan model pembelajaran $N H T$ dengan melihat pengaruhnya terhadap pemahaman konsep fisika siswa dengan materi yang berbeda.

\section{DAFTAR PUSTAKA}

[1] P. Suparno, Metodologi Pembelajaran Fisika, Konstruktivistik Dan Menyenangkan, Yogyakarta, Indonesia : Universitas Sanata Dharma, 2013.

[2] N. Subrtha, "Pengembangan Model Pembelajaran Kooperatif Dan Strategi Pemecahan Masalah Untuk Meningkatkan Hasil Belajar Siswa Kelas VIIC Smp Negeri 1 Sukasada", Jurnal Penelitian dan Pengembangan Lembaga Penelitian Undiksha, vol. 1,pp. 2. 2007.

[3] Yusuf dan Sugandhi, Perkembangan Peserta Didik. Jakarta, Indonesia: Rajawali Press. 2012.

[4] Trianto, "Konsep, Landasan Dan Implementasinya Pada Kurikulum Tingkat Satuan Pendidikan (KTSP)", Mendesain Model Pembelajaran Inovatif-Progresif. Jakarta, Indonesia: Kencana Prenada Media, 2009.

[5] Febiliyanti, Pengaruh Model Pembelajaran Kooperatif Tipe NHT (Numbered Heads Together) Terhadap Hasil Belajar Siswa kelas XI IPA SMA Negeri 1 Dolo Pada Materi Pelajaran Kimia Koloid, Jurnal Jurusan Pendidikan Kimia Fakultas Keguruan dan IImu Pendidikan Universitas Tadulako, vol.3.2,pp. 98103. 2014.

[6] Idayani, Penerapan Model Pembelajaran Numbered Head Together Untuk Meningkatkan Prestasi Belajar IPA Siswa Kelas V Semester II SD 2 Bulungkulon Jekulo Kudus Tahun Ajaran 2012/2013. Skripsi. Universitias Maria Kudus. 2013.

[7] A. Rasyid, Pengaruh Model Pembelajaran Kooperatif Tipe NHT (Numbered Head Together) dan Kemampuan Awal Terhadap Hasil Belajar Siswa Pada Mata Pelajaran Fisika di SMP Negeri 2 Poso, Jurnal Jurusan Pendidikan Fisika Fakultas Keguruan dan Ilmu Pendidikan Universitas Tadulako, vol.3.1, pp. 61-68. 2015.

[8] Karmila, Pengaruh Model Pembelajaran Kooperatif Tipe Numbered Head Together Dengan Pendekatan Contextual Teaching And Learning Terhdap Hasil Belajar Fisika Siswa Kelas VIII SMP Negeri 2 Balaesang, Skripsi Jurusan Pendidikan Fisika Fakultas Keguruan dan Ilmu Pendidikan Universitas Tadulako.(Tidak dipublikasikan), 2014. 